\title{
THE ROLE OF FUNCTIONAL FRUITS AND VEGETABLES ON HEALTH
}

\author{
Siswanto \\ Director, Center for Applied Health Technology and Clinical Epidemiology \\ National Institute of Health Research and Development, MoH RI \\ siswantos@yahoo.com
}

\begin{abstract}
In the last three decades, there has been an evolution of nutrition science from classical nutrition science covering macro and micro nutrients into current nutrition science that elaborate not only basic nutrients (macro and micro nutrients) but also functional foods and omic science of nutrition (nutrigenomics and nutrigenetics). There are 7 categories of bioactive compounds in fruits and vegetables considered as functional foods, i.e. carotenoids, dietary fibre, fatty acids, phenolics (flavonoids), plant sterols, prebiotics/probiotics, and soy phytoestrogens. One category of functional foods which is believed to be important for degenerative disease prevention is phenolic compounds, considered as antioxidants. In principle, antioxidants will neutralise free radicals (radical oxygen species and radical nitrogen species) by donating their electron. Free radical is believed to cause inflammation and destruction of cell structure which in turn would cause the occurrence of degenerative diseases. Therefore, antioxidants are claimed as physiologically active compounds that can prevent a number of degenerative diseases, like cancer, cardiovascular disease, cataract, macular degeneration, chronic lung diseases, immune deficiency diseases, Diabetes Melitus, in facts, HIVIAIDS.
\end{abstract}

Keywords: functional foods, bioactive compounds, degenerative disease

\section{ABSTRAK}

\section{PERAN BUAH DAN SAYUR FUNGSIONAL TERHADAP KESEHATAN}

Dalam tiga dekade terakhir terjadi evolusi pada perkembangan ilmu Gizi, dari ilmu gizi klasik yang mencakup gizi makro dan mikro ke arah ilmu gizi masa kini yang menggali tidak saja ilmu gizi dasar tetapi juga pangan fungsional dan ilmu Omic dalam Gizi. (nutrigenomic dan nutrigenetik). Terdapat 7 jenis komponen bioaktif dalam buah dan sayuran yang disebut pangan fungsional, seperti karotenoid, serat, asam lemak, phenol (flavonoids), sterol dari tanaman, prebiotik dan probiotik, dan kedelai phytoestrogens. Satu jenis pangan fungsional yang dipercaya sangat penting dalam mencegah penyakit degenerative adalah senyawa phenol, termasuk dalam golongan antioksidan. Prinsipnya, antioksidan akan menetralisir radikal bebas(radical oxygen species dan radical nitrogen species) dengan memeberikan elektronnya. Radikal bebeas dipercaya dapat menyebabkan inflamasi dan penghancuran struktur sel yang pada akhirnya akan menyebabkan terjadinya penyakit degeneratif. Karena itu, oksidan diakui sebagai senyawa aktif secara physiologik yang dapat mencegah sejumlah penyakit degeneratif, seperti kanker, penyakit jantung dan pembuluh darah, katarak, degenerasi makular, penyakit kronis paru, penyakit kekurangan imun, kencing manis, dan termasuk HIVIAIDS.

Kata kunci: pangan fungsional, senyawa bioaktif, penyakit degeneratif

\section{INTRODUCTION}

B ased on nutrition science, there are five important basic nutrition that human body should obtain in adequate amount to keep a healthy life, i.e. carbohydrate, protein, fat, vitamins and minerals. Carbohydrate, protein and fat are categorised as macronutrition; whereas vitamins and mineral categorised as micro-nutrition. ${ }^{1}$

However, within the last five decades nutrition science and medical science have identified that some foods can function not only as basic nutrition (macro and micro nutrition), but they have the functions for health maintenance, disease prevention, in facts for disease treatment. ${ }^{2}$ These kinds of foods contains physiologically active compounds that benefits for disease prevention and treatment. To mention, polyunsaturated fatty acids for heart disease prevention, fibre for prevention of colon malignancy, probiotics for gastrointestinal health, antioxidants for degenerative disease prevention, and still many others. 
Most of the physiologically active compounds that functions as functional foods are originated from food stuff of fruits and vegetables. ${ }^{3}$

Even though vegetables and fruits are very important as source of functional foods, consumption of vegetables and fruits of Indonesian people is still not adequate compared to WHO recommended intake. According to 2007 Basic Health Research, by asking the consumption of vegetables and fruits within the last 7 day period, has shown that for people aged more than 10 years, the proportion of those who were lack of vegetable and fruit consumption was 93.6 percent, indicating that those who were adequate of vegetable and fruit consumption was only 6.4 percent. $^{4}$

The objective of this paper is to explore the role of fruits and vegetables as functional foods. There will be explored the issues of (i) evolution of nutrition science, (ii) functional foods, (iii) anti-oxidants and diseases, (iv) oxidative stress and antioxidants, and finally (v) conclusion.

\section{EVOLUTION OF NUTRITION SCIENCE}

In principle, scientists have known that there was an association between nutrition and health, in facts, between nutrition and disease. Classical example of association between nutrients and disease was the finding of Eijkman research. In 1896, after ten years of research in Batavia Eijkman has proved that there was an association between polished rice (rice without thin skin) with the occurrence of Beriberi. In his research, Eijkman concluded that the thin skin of rice has "anti Beriberi factor", which was finally known as Thiamine (Vitamin B1). In fact, Eijkman said that: "white rice can be poisonous!". What Eijkman said that white rice can be poisonous is white rice (polished rice). Polished rice has been removed of their thin skin, which is rich of Vitamin B1. The finding of Eijkman research has shown that there was an association between nutrition intake and disease. $.5,6$

In terms of nutrition science, an evolution has occurred from classical nutrition science to functional nutrition science. Classical nutrition science tried to explore the basic nutrients of human body, like macro-nutrients and micro-nutrients; whereas functional nutrition has gone beyond these issues. Functional nutrition tried to explore and identify physiologically active compounds that have health benefits for health maintenance, disease prevention, and disease therapy. The evolution of nutrition science from classical nutrition science to current nutrition science is as shown in Figure 1.

It can be seen from Figure 1, that current nutrition science has gone beyond classical nutrition science on which only elaborates macronutrients and micronutrient, but the science has advanced to explore the role of foods in healthy physiological function of human body (functional foods), in facts, there is an emerging knowledge from the perspective of omic science for nutrition (nutrigenomic and nutrigenetics). ${ }^{7}$

With regard of the association between food and diseases, within the last three decades there have emerged new terms i.e. nutraceutical and functional foods. Some references and books use inter-exchangeable the terms of nutraceutical and functional foods. Nutraceutical is defined as any substance that may be considered a food or part of food that has potency to provide medical or health benefits, including the prevention and treatment of disease. So, basically, nutraceutical is a hybrid of nutrition and pharmaceutical. Whereas, functional foods are the foods that have a potentially positive effect on health beyond basic nutrition (macronutrients and micro-nutrients). Therefore, it can be said that functional foods are part of foods; and nutraceutical are part of functional foods. All foods are functional as they provide varying amounts of nutrients and energy to sustain growth and vital processes. However, functional foods are generally considered to be able offering additional benefits that may reduce the risk of disease or promote optimal health. ${ }^{8}$

\section{FUNCTIONAL FOODS}

As has been mentioned that functional foods are foods that contain physiologically active compounds that have medical benefits, such as prevention and treatment of disease. For example, yoghurts that contain active lactobacillus, salmon that contain omega-3, vegetable oil that contain 
polyunsaturated fatty acids, fruits that contain flavonoids (anti-oxidants), tomato that contain lycophene, etc. These kinds of physiologically active compounds are believed to effect on disease prevention or disease treatment.

International Food Information Council categorised functional food into 7 groups, i.e. (i) carotenoids, (ii) dietary fibre, (iii) fatty acids, (iv) phenolics, (v) plant sterols, (vi) prebiotics / probiotics, and (vii) soy phytoestrogens. ${ }^{9}$ More detail category and their function are as shown in Table 1.

From Table 1, it can be seen that functional foods are foods that contain physiologically active compounds, either chemical active compounds or bacteria, and these active compounds have the benefit effect on health maintenance, disease prevention, or disease treatment. It should be emphasized that the mechanism of action of active compounds in functional food is beyond the action of basic nutrient (macro and micro nutrient) (see Column 3 in Table 1).

\section{ANTI-OXIDANT AND DISEASES}

In recent knowledge, all degenerative diseases in human body are believed to be caused by oxidative stress and inflammation. Stress and inflammation are caused by free radicals, namely reactive oxygen species (ROS) and reactive nitrogen species (RNS). Free radicals for ROS species are hydroxyl radical, superoxide anion-radical, hydrogen peroxide; whereas for RNS species are nitrogen dioxide, and peroxinitrite. The phenomenon of free radicals is basically the consequences of normal respiratory process at cellular level. Mitochondria is cell organelle which is responsible for respiratory process, as this cellular organelle is responsible for producing Adenosine Tri Phosphate (ATP) for energy. The energy is important for maintaining physiological function of the body. However, from the process of ATP production, cells will produce metabolites of free radicals. i.e. ROS and RNS. ${ }^{10}$

Even though the generation of free radicals is naturally physiological, the production of them in human body would be increased by two factors, namely exogenous factors and endogenous factors. ${ }^{11}$ The exogenous factors are consisting of physical environmental factors (i.e. radioactivity, ultraviolet, irradiation, air pollution, etc.), and of chemical substance intake (i.e. drugs, antibiotics, hormones, alcohol, tobacco smoke). The endogenous factors are consisting of metabolic disorders (increased activities of oxidase i.e. xanthine oxidase, urate oxidase, aldehyd oxidase), mitochondrial diseases, increased activity of Cytochrome P450, and decreased respiration efficiency due to aging. ${ }^{11}$

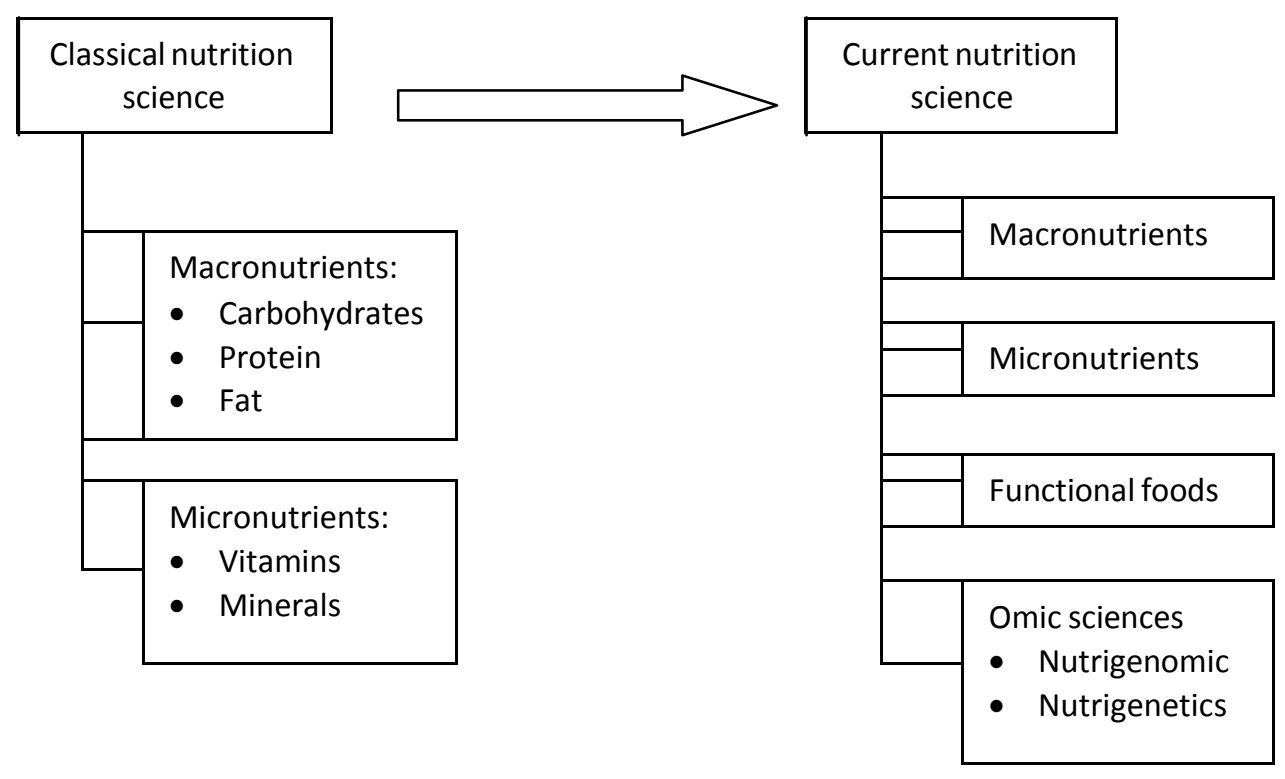

Figure 1

The Evolution of Nutrition Science 
Table 1

Category of Functional Foods and Their Functions

\begin{tabular}{|c|c|c|c|}
\hline Category & Compounds & Source & Functions \\
\hline \multirow[t]{3}{*}{ Carotenoids } & $\begin{array}{l}\text { Alpha-carotene/Beta- } \\
\text { carotene }\end{array}$ & $\begin{array}{l}\text { Carrots, fruits, } \\
\text { vegetables }\end{array}$ & $\begin{array}{l}\text { Neutralize free radicals, which } \\
\text { may cause damage to cells }\end{array}$ \\
\hline & Lutein & Green vegetables & $\begin{array}{l}\text { Reduce the risk of } \\
\text { macular degeneration }\end{array}$ \\
\hline & Lycopene & $\begin{array}{l}\text { Tomato products (ketchup, } \\
\text { sauces) }\end{array}$ & $\begin{array}{l}\text { Reduce the risk of } \\
\text { prostate cancer }\end{array}$ \\
\hline \multirow[t]{3}{*}{ Dietary fibre } & Insoluble fibre & Wheat bran & $\begin{array}{l}\text { Reduce risk of breast or colon } \\
\text { cancer }\end{array}$ \\
\hline & Beta-glucan & Oats, barley & $\begin{array}{l}\text { Reduce risk of cardiovascular } \\
\text { disease. Protect against heart } \\
\text { disease and some cancers; } \\
\text { lower LDL and total cholesterol }\end{array}$ \\
\hline & Soluble Fibre & Psyllium & $\begin{array}{l}\text { Reduce risk of cardiovascular } \\
\text { disease. Protect against heart } \\
\text { disease and some cancers; } \\
\text { lower LDL and total cholesterol }\end{array}$ \\
\hline \multirow[t]{2}{*}{ Fatty acids } & $\begin{array}{l}\text { Long chain omega-3 } \\
\text { Fatty Acids-DHA/EPA }\end{array}$ & Salmon and other fish oils & $\begin{array}{l}\text { Reduce risk of cardiovascular } \\
\text { disease. Improve mental, visual } \\
\text { functions }\end{array}$ \\
\hline & $\begin{array}{l}\text { Conjugated Linoleic } \\
\text { Acid (CLA) }\end{array}$ & $\begin{array}{l}\text { Cheese, meat } \\
\text { products }\end{array}$ & $\begin{array}{l}\text { Improve body composition. } \\
\text { Decrease risk of certain }\end{array}$ \\
\hline Plant sterols & Stanol ester & $\begin{array}{l}\text { Corn, soy, wheat, wood } \\
\text { oils }\end{array}$ & $\begin{array}{l}\text { Lower blood cholesterol levels } \\
\text { by inhibiting cholesterol } \\
\text { absorption }\end{array}$ \\
\hline \multirow[t]{6}{*}{$\begin{array}{l}\text { Phenolics } \\
\text { (antioxidants) }\end{array}$} & Anthocyanidins & Fruits & $\begin{array}{l}\text { Neutralize free radicals; reduce } \\
\text { risk of cancer }\end{array}$ \\
\hline & Catechins & Tea & $\begin{array}{l}\text { Neutralize free radicals; reduce } \\
\text { risk of cancer }\end{array}$ \\
\hline & Flavonones & Citrus & $\begin{array}{l}\text { Neutralize free radicals; reduce } \\
\text { risk of cancer }\end{array}$ \\
\hline & Flavones & Fruits/vegetables & $\begin{array}{l}\text { Neutralize free radicals; reduce } \\
\text { risk of cancer }\end{array}$ \\
\hline & Lignans & $\begin{array}{l}\text { Flax, rye, } \\
\text { vegetables }\end{array}$ & $\begin{array}{l}\text { Prevention of cancer, } \\
\text { renal failure }\end{array}$ \\
\hline & $\begin{array}{l}\text { Tannins } \\
\text { (proanthocyanidines) }\end{array}$ & $\begin{array}{l}\text { Cranberries, cranberry } \\
\text { products, cocoa, chocolate }\end{array}$ & $\begin{array}{l}\text { Improve urinary tract health. } \\
\text { Reduce risk of cardiovascular } \\
\text { disease }\end{array}$ \\
\hline \multirow[t]{2}{*}{$\begin{array}{l}\text { Prebiotics/ } \\
\text { probiotics }\end{array}$} & $\begin{array}{l}\text { Fructo- } \\
\text { oligosaccharides } \\
\text { (FOS) }\end{array}$ & $\begin{array}{l}\text { Jerusalem artichokes, } \\
\text { shallots, onion powder }\end{array}$ & $\begin{array}{l}\text { Improve quality of intestinal } \\
\text { microflora; gastrointestinal } \\
\text { health }\end{array}$ \\
\hline & Lactobacillus & Yogurt, other dairy & $\begin{array}{l}\text { Improve quality of intestinal } \\
\text { microflora; gastrointestinal } \\
\text { health }\end{array}$ \\
\hline $\begin{array}{l}\text { Soy } \\
\text { phytoestrogens }\end{array}$ & $\begin{array}{l}\text { Isoflavones: Daidzein } \\
\text { Genistein }\end{array}$ & $\begin{array}{l}\text { Soybeans and soy- based } \\
\text { foods }\end{array}$ & $\begin{array}{l}\text { Menopause symptoms, such as } \\
\text { hot flashes Protect against heart } \\
\text { disease and some cancers; } \\
\text { lower LDL and total cholesterol }\end{array}$ \\
\hline
\end{tabular}

To neutralise free radicals (ROS and RNS), anti-oxidants is very important. Anti-oxidants are basically chemical substances which has free electron. This free electron would neutralise 
active oxygen in free radical metabolites. Therefore, the process of inflammation as the consequence of oxidative stress can be prevented or minimized. From here, it is believed that degenerative diseases can be prevented. Abundant sources of anti-oxidants (phenolic compounds) can be obtained from fruits and vegetables. In phenolic compounds, basically they have double bond of carbon and hydroxyl branch that can donate free electron for ROS and RNS. However, fruits and vegetables are not solely as anti-oxidants in properties, but they have also another group of active compounds, as have been mentioned in Table 1.

Antioxidants are compounds that protect cells from the damage caused by oxidation. Anti means "against," and antioxidants work against, or prevent oxidation. The process by which the body breaks down and builds up molecules is called metabolism. During metabolism, atoms may lose electrons. This loss of electrons is called oxidation, because it is fuelled by oxygen. Atoms are capable of gaining electrons during metabolism as well.
This process is called reduction. This loss and gain of electrons typically results in an even exchange of electrons. Scientists call this loss and gain of electrons an exchange reaction (redox) (see Figure 2).

In most exchange reactions, two atoms with unpaired electrons immediately pair up, making newly stabilized molecules, but in rare cases, atoms with unpaired electrons in their outermost shell remain unpaired. Such atoms are highly unstable and are called free radicals. When an oxygen molecule becomes a free radical, it is referred to as a reactive oxygen species (ROS). In the same way, for nitrogen molecules, it is referred to as reactive nitrogen species (RNS). If the amount of free radicals in the human body is abundant, the situation is labelled as oxidative stress. This situation would promote destruction of cell membranes, mitochondria, DNA, RNA, and telomerase shortening, and then consequently would improve the risk of degenerative diseases, like cancer, diabetes, cardiovascular diseases, and others.

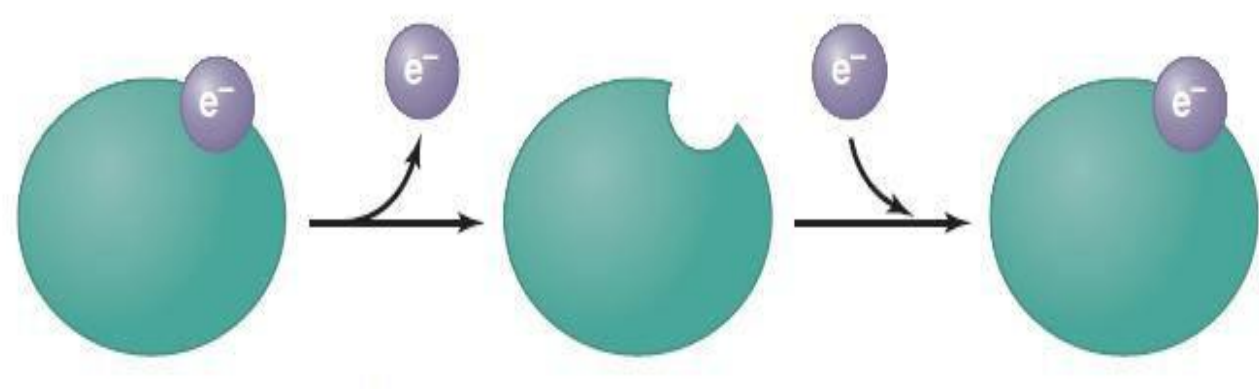

(a) Oxidation

(b) Reduction

Figure 2

Exchange reactions consist of two parts. (a) During oxidation, molecules lose electrons. (b) In the second part of the reaction, molecules gain electrons, which is called reduction. 


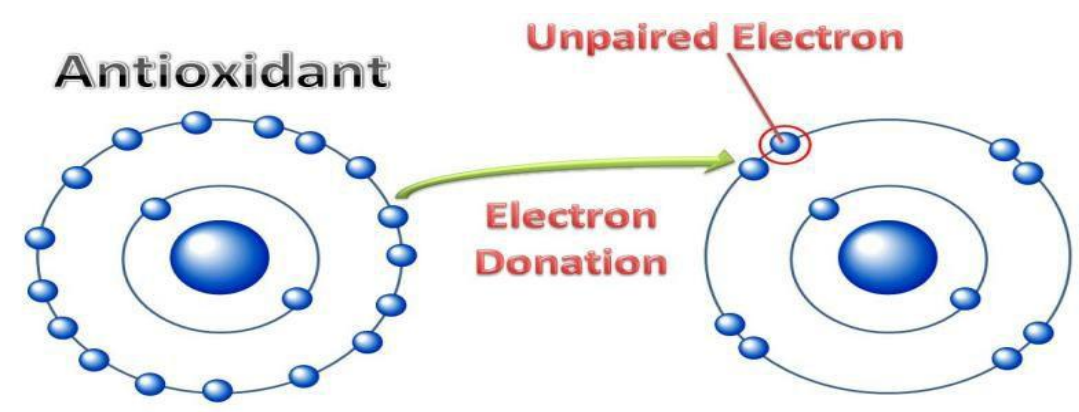

Free Radical

Figure 3

How anti-oxidants neutralise free radicals by giving electron to free radicals to be a stable molecule

Table 2

Diseases that Can Be Associated with Oxidative Stress (Free Radicals)

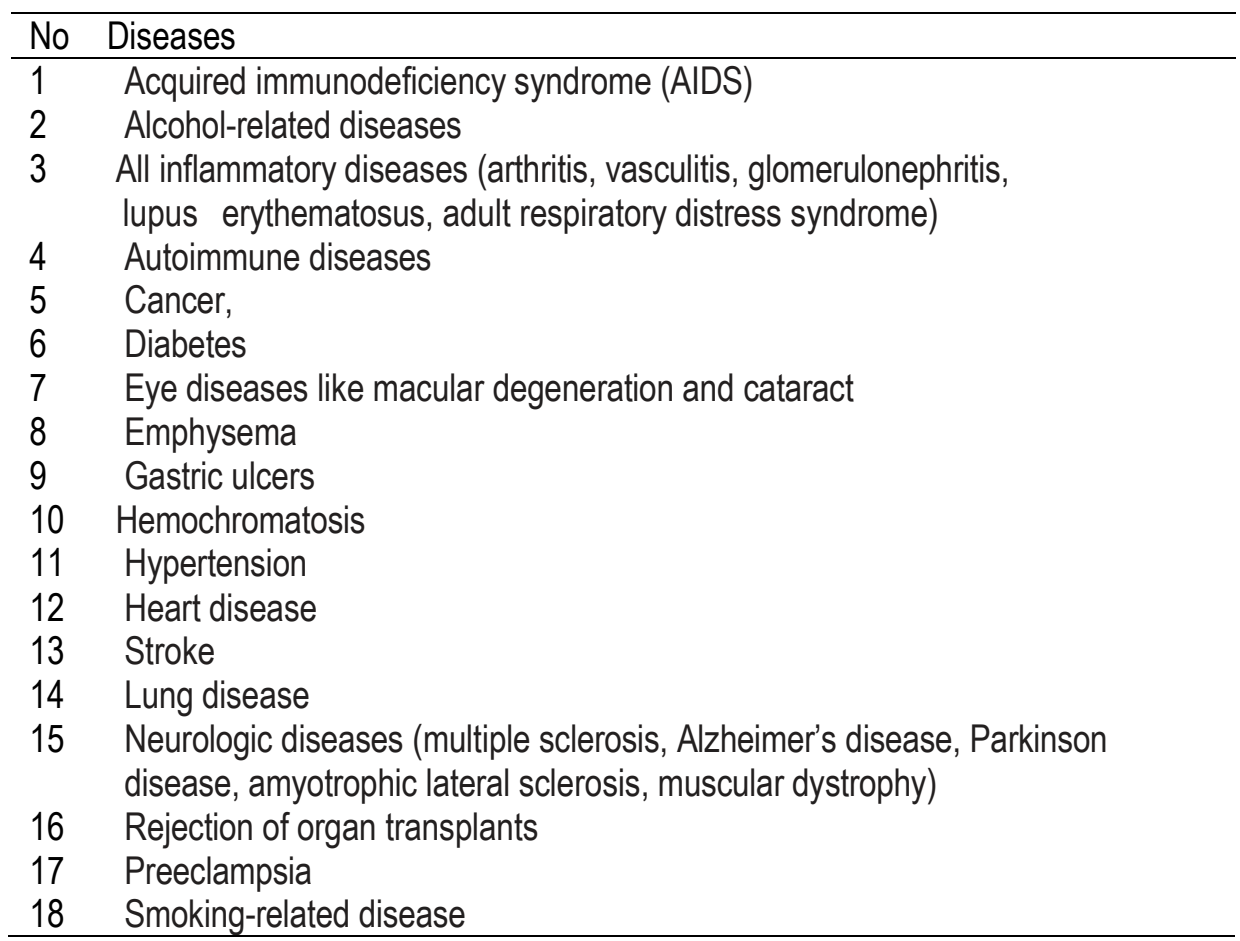

A group of anti-oxidant compounds i.e. (i) flavonoids, (ii) tannins, (iii) chalnones and coumarins, and (iv) phenolic acids has the capability of donating electron to free radical molecules (ROS and RNS) (see Figure 3). Free radicals which are responsible for inflammation process can be stabilised by antioxidants. By this way, anti-oxidant can prevent degenerative diseases which are believed due to inflammation process.
OXIDATIVE STRESS AND ANTI-OXIDANTS

As has been mentioned that anti-oxidants sources are fruits and vegetables. In facts, fruits and vegetable are not only the sources of anti-oxidants, but also the sources of other active compounds acting as functional foods like carotenoids, dietary fibre, fatty acids, plant sterols, prebiotics, and phytoestrogens. Antioxidants are very important for neutralising free radicals to prevent degenerative diseases 
and aging. While the rests are also important for health maintenance and disease prevention.

There are a number of diseases that are related to oxidative stress (free radicals) (Lushchak and Gospordayov, 2012)12, as shown in Table 2.

From Table 2, it can be seen that in principle almost all degenerative diseases and diseases associated with immune disorders (AIDS, inflammatory diseases, autoimmune diseases) can be associated with oxidative stress (free radicals). Therefore, to decrease risk factors of contracting such diseases the consumption of food and vegetables that contain antioxidants is very important. Sources of fruits and vegetables with abundant antioxidants can be seen in Table 3.

From Table 3, it can be seen that almost all of fruits and spices have phenolic compounds that function as anti-oxidant. Even though the data are basically from foreign fruits, it does not necessary that local fruits do not have the potency of antioxidants. Indonesian researchers should explore the content of antioxidants in tropical fruits (Indonesian fruits).

Table 3

Sources of Antioxidants in Fruits and Spices (Gonzales, 2013)

\begin{tabular}{lc}
\hline Source & Total phenolics $\mathbf{( m g \% )}$ \\
\hline Shallot & 1718 \\
Sweet onion & 142 \\
Thyme & 1646 \\
Tumeric & 176 \\
Fruits & \\
Apple, green & 118 \\
Apple, red & 125 \\
Apple, yellow & 100 \\
Blueberry & 362 \\
Cherry, sour & 156 \\
Cherry, sweet & 79 \\
Grape, black & 213 \\
Grape, white & 184 \\
Grapefruit & 893 \\
Guava, pink fresh & 247 \\
Guava. white fresh & 145 \\
Kiwi & 791 \\
Lemon & 843 \\
Lime & 751 \\
Litchi & 60 \\
Nectarine, white flesh & 38 \\
Nectarine, yellow flesh & 25 \\
Orange, sweet & 1343 \\
Peach, white flesh & 53 \\
Peach. vellow flesh & 35 \\
Pear & 125 \\
Pineapple & 94 \\
Plum, black & 88 \\
Plum, red & 73 \\
Pomegranate & 147 \\
Pomelo & 57 \\
Raspberry black & 670 \\
\hline &
\end{tabular}




\section{CONCLUSION}

From the paper it can be concluded the following points: There has been an evolution nutrition science from classical nutrition science covering macro and micro nutrients into current nutrition science that has elaborated not only basic nutrients (macro and micro nutrients) but also functional foods and omic science of nutrition (nutrigenomics and nutrigenetics) in the last three decades. Besides, Fruits and vegetables which have rich of nutrient contents of vitamins, minerals, There are also important compunds, namely bioactive compounds. There are 7 categories of bioactive compounds in fruits and vegetables, e.g. carotenoids, dietary fibre, fatty acids, phenolics (flavonoids), plant sterols, prebiotics/probiotics, and soy phytoestrogens, which are considered as functional foods. The way of functional foods to prevent degenerative diseases is primarily through "antioxidant mechanism" i.e. by donating electron to free radicals (reactive oxygen species and reactive nitrogen species) to be stable molecules. The diseases can be prevented by antioxidants are basically degenerative diseases and immune disorders, e.g.: cancer, cardiovascular disease, cataract, macular degeneration, chronic lung diseases, immune deficiency diseases, Diabetes Melitus, HIVIAIDS, etc.

\section{REFERENCES}

1. Whitney EN, Rolfes SR. Understanding Nutrition. Eighth Edition. New York: West Wadsworth, 1999.

2. Paliyath G, Bakovic M, Shetty K. Functional Foods, Nutraceuticals, and Degenerative Disease Prevention. West Susex: WileyBlackwell, 2011.
3. Mann J, dan Truswell SA. Essentials of Human Nutrition. London: Oxford University Press, 1998.

4. Basic Health Research. National Institute of Health Research and Development. Basic Health Research. National Report. Jakarta: National Institute of Health Research and Development, 2007.

5. McDowel LR. Vitamin History, The Early Years. Florida:University of Florida, 2013.

6. Frankenburg FR. Vitamin Discoveries and Disasters, History, Science and Contraversies. California: Greenwood Publishing, 2009.

7. Mutch DM, Wahli W, Williamson G. Nutrigenomics and nutrigenetics: the emerging faces of nutrition. The FASEB J. 2005;19(12):1602-1616.

8. Hasler CM. Fuctional Food: the role in disease prevention and health promotion, a publication of the institute of food technologists expert panel on food safety and nutrition. Journal Food Technology 1998;52(11):12-20.

9. International Food Information Council. Category of Functional Foods. Available from: www.foodinsight.org, October 10th, 2013.

10. Stephanie T, Sobey CG, Grant R. Oxidative stress and endothelial dysfunction .Drummond. In Endothelial Dysfunction and Inflamation, editors : Shauna M. Dauphinee Karsan A. London: Springer, 2010. p: 3764.

11. Gonzales, M. Oxidative Stress and Chronic Degenerative Diseases, A Role for Antioxidants. Croatia: In Tech, 2013.

12. Lushchak G. Oxidative Stress and Diseases. Croatia: In Tech. 2012. 